\title{
Re-visions of Volumnia's Motherhood
}

\author{
$\mathrm{M}^{\mathrm{a}}$ José Álvarez Faedo \\ University of Oviedo \\ mjfaedo@pinon.ccu.uniovi.es
}

\begin{abstract}
The last decades have witnessed the appearance and consolidation of feminist Shakespearean criticism as a challenging -and therefore harshly attackedcritical project. This article explores and revises the interpretations feminist criticism has offered of the concept of motherhood concerning the character of Volumnia in Coriolanus, from two different points of view: the Psychoanalytic approach and the political perspective -integrating the British Cultural Materialist and the American New Historicist views. From this New Historicist perspective, a new approach to the question of Volumnia's motherhood is suggested, by adding, to classical interpretations, a new one, offering an analysis of Volumnia as a Renaissance 'new mother'.
\end{abstract}

An interesting feature of the study of Shakespearean drama in the last decades has been refreshing rediscovery and revision of the playwright's female characters and of his psychological and historical portrayal of women. ${ }^{1}$ From Margaret Cavendish in her Sociable Letters (1664) -according to Ann Thompson and Sasha Roberts (1997: 2), the author of "the first critical essay ever to be published on Shakespeare" - to Kate Chedgzoy's Shakespeare, Feminism and Gender (2001), feminist criticism has offered a new, though sometimes challenged and harshly attacked ${ }^{2}$, reading of Shakespeare's plays.

This article revises the feminist criticism on one of William Shakespeare's female characters, Volumnia, and on her role as Caius Martius Coriolanus's mother. To that aim, this study will be divided into two main parts, corresponding to distinct critical movements 
which bave interacted with the related feminist critical project: the Psychoanalytic approach and the political perspectives (the Cultural Materialist and the New Historicist views). ${ }^{3}$

\section{A Feminist Psychoanalysis of Volumnia in the Late 20th Century}

In order to explore the interpretations that feminist psychoanalytic criticism - being Janet Adelman probably its most outstanding exponent-has offered of the character of Volumnia in this sense, I shall present a progressive psychoanalytic analysis of her evolution as Coriolanus's mother: beginning with her role as a 'creator', who later refuses to be a 'nourisher', managing, nevertheless, to exert great 'power and control' over her son, which provokes 'his dependency on her', and which will ultimately lead to her punishing him, in her role of non-nourishing 'cannibalistic' mother.

\subsection{Volumnia: a Mother and a Creator}

Janet Adelman suggests that "Volumnia takes some pride in the creation of her son", and she supports her argument explaining that "when we first meet her, she tells us exactly how she's done it: by sending him to a cruel war at an age when a mother should not be willing to allow a son out of the protective maternal circle for an hour" (1992: 148). In this respect, Patricia Shaw (1990: 32) finds related evidence in Shakespeare, and affirms that "Macbeth's injunction to 'bring forth men-children only' would be eminently appropriate too for this martial-minded and patriotic Roman matron, who glories in her son's wounds." However, it is not cruelty that leads her to behave like that, but her motherly instinct, which wished the best for her son's future: "I, considering how honour would become such a person [...] was pleased to let him seek danger where he was like to find fame" (I.iii.8-11).

We should not forget that Volumnia is a widow who has to bring up her only son alone. Shakespeare exploits that idea and presents us with a Roman matron who has devoted her life to turning his only child into what he is: a warrior. In trying to avoid bringing up Coriolanus as a weak man, she is determined to turn him into a glorious warrior from the very beginning, since - from her point of view - the thrill of giving birth to ('creating') Coriolanus parallels that of seeing him as a soldier: "I sprang not more joy at first hearing he was a man-child than now in first seeing he had proved himself a man" (I.iii.13-14). ${ }^{4}$

In the last Act (V.iii. 120-124), she identifies herself with Rome, the city he is about to destroy. Adelman (1992: 160) interprets this in the following terms: "the ruin on which Coriolanus will tread will be his mother's womb - a warning accompanied by yet another assertion of his dependence on her as she recalls to him the image of himself as a fetus within the womb". When he threatens to march against his own country he is also threatening to destroy his genetrix, because he was engendered to defend and safeguard Rome, his motherland. By destroying his motherland -significantly represented here by the image of the "womb"- he destroys all the hopes his own mother has placed on him on the day of his "creation" and the very reason why he had been conceived. 


\subsection{The Mother's Refusal to Be a 'Nourisher'}

Janet Adelman finds Volumnia's attitude towards feeding "most disturbing" $(1992 ; 148)$ in these lines of Coriolanus: "The breasts of Hecuba, / When she did suckle Hector, looked not lovelier / Than Hector's forehead when it spit forth blood / At Grecian sword contemning" (I.iii.35-38), because "he is transformed immediately from infantile feeding mouth to bleeding wound" (1992: 148). The critic proceeds to explain that, as the child's mouth acts as the sole link between breast and wound, "to feed is to be wounded; the mouth becomes the wound, the breast the sword" (1992: 149). She interprets that metaphor as a psychological fact: our being fed symbolises our dependence on the world, and, therefore, the fact that we are vulnerable. But she still goes a step further in her interpretation:

... as Volumnia's image suggests the vulnerability inherent in feeding, it also suggests a way to fend off that vulnerability. In her image, feeding, incorporating, is transformed into spitting out, an aggressive expelling [...]. The wound spitting blood thus becomes not a sign of vulnerability but an instrument of attack. (1992: 149)

Volumnia's attitude towards food is going to influence and bias her son's behaviour, to the extent that "in the transformation from oral neediness to phallic aggression, anger becomes his meat as well as his mother's" (1992: 150) ${ }^{5}$. And, accordingly, she is furious when she finds out that, filled with rage against those who had betrayed him, he has joined the enemy to attack Rome. If we interpret 'fighting' as a substitute for 'feeding', "and the unsatisfied ravenous attack of the infant on the breast provides the motive force for warfare", we can "understand the ease with which Coriolanus turns his rage toward his own feeding mother, Rome" (1992: 150), since the city deprives him of the only nourishment she can grant him: the victory in the elections, and therefore, the powerful position of consul.

\subsection{The Power of Motherhood}

Shakespeare builds up the relationship between mother and son and emphasises the influence that the Roman matron always exercised over "fatherless" Coriolanus, who was "terribly subject to her power" (1992: 130). The relationship between mother and son was an unusually close (though perfectly natural) attachment between two people who had meant everything to each other and who respected each other as well. Throughout his life, Coriolanus had tried to satisfy his mother's opinion and live up to the ideals she had taught him. Plutarch ${ }^{6}$ describes Coriolanus's feelings towards his mother in the following terms: "nothing made him so happy and honourable as that his mother might hear everybody praise and commend him; that she might always see him return with a crown upon his head; and that she might still embrace him with tears running down her cheeks for joy" (Spencer, 1968 [1964]: 300). Plutarch's narrative emphasizes how Volumnia's matriarchal status was a decisive influence in every step of her son's life, to the extent that "at her desire [he] took a wife also, by whom he had two children; and yet never left his mother's house therefore" 
(Spencer, 1968 [1964]: 300). Similarly, Shakespeare's Volumnia certainly moulded her son's character, as A. D. Nuttal (1983) affirmed, but, after all -as Coppélia Kahn (1997) suggested-, that was what was expected of her as a Roman matron, and I would add that also as a 'mother figure' created by a Renaissance playwright, since, as Erasmus affirmed (Wayne, 1996), a Renaissance mother had to 'frame her child's body and mind with good education'.

Volumnia's aim seems to have been to make her son into her image of a perfect Roman citizen and, in the process, she has made him a reflection of herself in valour, and perscnal honour. However, he did not inherit his 'pride' from her: she is more diplomatic. This is shown in Shakespeare's play (III.ii.40-93) when Volumnia, in pursuance of her political ambitions for her son, tries to teach him the importance of diplomacy in politics and asks him to humble himself to the people. Unfortunately, her son does not follow her advice, and consequently he is punished, being sentenced to perpetual banishment. Volumnia is consoled by her son at a city gate (IV.i). Recalling the precepts she had taught him, "being gentle wounded, craves a noble cunning" (IV.i.8-9), he reminds her that a gentlemanly spirit best reveals itself in adverse situations. But even if, in this scene, Coriolanus seems to gain strength and to control the situation better than his mother, it is indisputable that, nevertheless, as Adelman penned (1992:152): "Coriolanus is acting under Volumnia's direction". And this "helps to explain both his bafflement when she suddenly starts to disapprove of the role she has created [...] and his eventual capitulation to her demand that he shift roles, here and at the end of the play" (1992: 152). Volumnia's power over her son is thus evident from the beginning to the end of the play, especially in Act V, when her wisdom and authority manage to bend the warrior's determination and to make him capitulate to her begging, even at the risk of his own life.

\subsection{The Child's Dependency on his Mother}

Coriolanus never actually succeeds "in separating himself from his mother", and, what is more, "even the very role through which he claims independence was designed by her" (1992: 152). We can first witness that dependency when, reaffirming her role as 'creator', Volumnia manages to make her son her own instrument, as she first describes how she imagines him in the battlefield: "Methinks I see him stamp thus, and call thus" (I.iii.27) and then utters his own words, performing the role she has designed for her son: "Come on, you cowards! You were got in fear, / Though you were born in Rome" (I.iii.28-29). Even at the end of the play "Coriolanus has not in fact succeeded in separating himself from his mother" (1992: 152), as Volumnia's words reveal: "Thou art my warrior; / I holp to frame thee" (V.iii.63-64).

Mother and son share their pride in military victories. Coriolanus wants to be a glorious soldier partly to please his mother, since her approval is more important to him than almost anything else. He can stand criticism from the people of Rome and hatred from his enemies, but he, on all occasions, needs to gain his mother's approval. That is the reason why, when Caius Martius Coriolanus is rejected in the election to create him consul, he cannot bear the 
affront with patience. Therefore I agree with Adelman (1992: 152) when she says that "his manhood is secure only when he can play the role that she has designed, and play it with her approval."

The critic interprets the conquest of Corioli as a "bloody rebirth", on the grounds that "for him, heroic masculinity turns on leaving the mother behind". From that perspective, the play is seen as a "paradox through which the son is never more the mother's creature than when he attempts to escape her" (1992: 130). But Adelman still offers further evidence for Coriolanus total dependence on his mother:

Volumnia had once before brought Coriolanus to submission by reminding him of himself as a suckling child (3.2.129); now virtually her last words enforce his identification with the child that she holds by the hand [...]. But at the same time she reminds him of his dependency, she disowns him by disclaiming her parenthood [...]. Just as his child entered the scene holding Volumnia's hand, so Coriolanus again becomes a child, holding his mother's hand. (1992:161)

The moment Coriolanus sees his mother in the Volscian camp, his sense of hierarchy and his code of honour remind him of the respect he ows her, of his dependency on her and of how he had always wished to please her. And that explains why, in the end, he decides to obey her and resolves not to attack Rome.

\subsection{From Non-Nourishing to Cannibalistic Motherhood}

The cannibalistic mother who denies food and yet feeds on the victories of her sweet son stands at the darkest center of the play, where Coriolanus's oral vulnerability is fully defined. Here, talion law reigns: the feeding infant himself will be devoured; the loving mother becomes the devourer. (1992: 158)

The episode referred to by Shakespeare in the scene with Sicinius and Brutus (IV.ii) is indeed interesting, since it offers us a further insight into the character of Volumnia: this lady's wisdom -aware as she is of the ubiquitous plots and treachery within the world of Roman politics-allows her to realise that both Sicinius and Brutus were the Machiavellian minds that had plotted to deprive her son of his well-deserved former prestige. Therefore, she does not hesitate for a moment to confront them openly, uttering imprecations, wishing that all the plagues of the gods fall on them. In this scene, Volumnia nourishes herself on the anger and despair a mother releases when, realising her son has been betrayed, she has the chance to confront his traitors.

Volumnia hoped that her Coriolanus would be ready to come back, triumphant, to help Rome when she needed him. However, she is heartbroken when she finds out that, filled with rage against those who had betrayed him, he has joined the enemy to attack Rome. Then, with Virgilia and her grandson, she goes in search of her son ${ }^{7}$ to beg him, in a moving speech, to realise the implications of his actions, and not to stain his own name, since, if he becomes a traitor to his country, the Roman matron's life would not have had any sense 
whatsoever, given that she had brought: "all the resources of her forceful personality and intelligence to bear on influencing Coriolanus for his own good and that of his country" (Shaw, 1990: 32).

Coriolanus's reaction at the sight of his mother and his wife in the Volscian camp is highly moving. In that scene Volumnia utters a sorrowful though harsh speech to her son, in which she accuses him of their current personal misery, and hints at the fact that it should have been otherwise. His behaviour, Volumnia denounces, is causing them great suffering and distress, and in a desperate attempt to make her son change his mind, she proceeds to deliver a speech worthy of the Roman matron she is:

\section{If I cannot persuade thee}

Rather to show a noble grace to both parts

Than seek the end of one, thou shalt no sooner

March to assault thy country than to tread-

Trust to't, thou shalt not - on thy mother's womb

That brought thee to this world (V.iii.120-125)

Coriolanus was brought to this world by his "mother's womb" (V.iii.124), where she could "mould" (III.ii. 104) him, which -in Kahn's words (1997: 148)- suggests that "the womb has power to shape the fetus, as distinct from the father's more exiguous contribution to its beginnings". According to the Oxford English Dictionary "mould" means not only "friable earth or topsoil", but also "earth regarded as the material of the human body" and "dust to which the human body returns after death", therefore it evokes the mythic connection existing between women, earth and death.

Thus, Volumnia's role is not just that of genetrix, nor just that of the one who 'frames' her son's temperament and value system; she will also be the one to determine his end, since -realising that he is not behaving according to the way she had expected him to--, she will have to be the one to stop him: "Trust to't, thou shalt not- on thy mother's womb / That brought thee to this world" (V.iii. 125-126).

But Coriolanus listens to his mother's speech without offering her a proper answer, and Volumnia, worried at seeing him rise and turn away, continues:

There's no man in the world

More bound to's mother, yet here he lets me prate

Like one i'th' stocks. Thou hast never in thy life

Showed thy dear mother any courtesy,

When she, poor hen, fond of no second brood,

Has clucked thee to the wars and safely home,

Loaden with honour. Say my request's unjust,

And spurn my back. But if it be not so,

Thou art not honest, and the gods will plague thee

That thou restrain'st from me the duty which 
To a mother's part belongs. - He turns away.

Down, ladies. Let us shame him with our knees. (V.iii.158-169)

Here she makes a great concession in humbling herself before her son -inverting the normal order of authority-, something she has never done before. But she had a good cause to undertake that startling act: the salvation of Rome. She can see beyond the limits of personal vengeance and she is infinitely more diplomatic, as well as more skilful in argument, than Coriolanus. Nevertheless, she exhausts all her diplomatic arguments of personal affection and of patriotism without receiving an answer from her son. It is not until, leaving her courteous manners aside, she openly defies him and turns on him with scorn that he reacts. Coriolanus cannot bear to lose his mother's good opinion, and he realises that his mother's contempt means that he has been unfaithful to her ideal of loyalty and service to Rome. ${ }^{8}$

Ironically, Volumnia knows that in saving Rome she is destroying the life of her son. She "wins the day, but, of course, in the last instance, the decision she has wrung out of him leads inexorably to his death" (Shaw, 1990: 32). She sees her duty here as being towards Rome, not towards her son, and she follows the path that she sees as the only right one. And finally she is hailed as a heroine in Rome, as indeed she is, because she embodies in her behaviour all the virtues for which Rome was popularly supposed to stand.

Volumnia seems to be a woman who has deliberately avoided the open displays of feminine affection in order to make her son a better warrior. They understand each other very well, they even seem to speak roughly to each other. But at the end of the play Volumnia teaches Coriolanus a final lesson -the lesson of seeking the glory of his country before his own personal glory. She is prepared to sacrifice him for Rome, and therefore he should be prepared to sacrifice himself for both her and Rome. She has taught him to be totally Roman, and he follows her, his mother, in this ideal as he always has. Nevertheless, I consider that behind it all, her motivation is love, but a love that is implied rather than actually spoken, and a love that is repressed by a stern code of honour.

\section{Volumnia in the Light of the Political Perspectives}

According to Catherine Belsey (1991: 236), "Materialist feminism points out that historically difference has implied domination, and that the subordination of women has no grounding in nature, or indeed in anything other than patriarchal appropriations of control in the service of self-interest". Judith Newton and Deborah Rosenfelt (1985: xix) note that this critical approach offers "an analysis of the circumstances of cultural production and an analysis of the complexities with which at a given moment in history they are inscribed in the text".

Perhaps precisely because Volumnia is determined to make her son achieve both honour and fame, at the beginning of the play (I.iii) she rejoices in his military heroism and explains the way she sent him to the "cruel war" when he was a mere boy. Proud of his wounds", she 
is extraordinarily ambitious for her beloved and admired son, both militarily and politically. Plutarch, in his account of the life of Coriolanus, had explained that "in those days valiantness was honoured in Rome above all other virtues" and insisted that "virtus in the Latin was as much as valiantness" (Spencer, 1968 [1964]: 297). But in trying so hard to avoid making a weak and cowardly man out of her son, Volumnia had erred in the opposite direction. She had insisted so strongly on his matchless skill and superiority that he lived by a code which glorified personal achievement for its own sake. Plutarch blamed some of Coriolanus's shortcomings on the limitations of his education, but Shakespeare instead of openly criticising the upbringing of his hero, he builds up the relationship between mother and son and emphasises the influence that the Roman matron always exercised over Coriolanus.

Like any historicist approach, mine is constructed according to the values and biases of Shakespeare and the particular historical moment in which he was writing: the English Renaissance. When a dramatist recreates a period of time different from the epoch he is living in, as Shakespeare does in Coriolanus (where he takes us back to Roman times) it is very difficult to avoid inserting some references to his own age. Actually, as early as 1961 Jan Kott suggested that Shakespeare's Rome in Coriolanus presented some anachronisms, pointing out that some of the props referred to in the play actually belonged to the playwright's contemporary England: "Coriolanus's mother and wife, sitting on some low chairs, sew, embroider and wait for news from the war. These low chairs, on which women talked away till dusk, can still be seen in Stratford nowadays." (Kott, 1969: 233).

This fact, supported by the evidence I am going to offer in the lines which follow, led me to enrich my perception of the character of Volumnia and to see her in a different light, by regarding her from a new perspective: as a Renaissance "new mother".

According to male Renaissance writers ${ }^{10}$, the ideal Christian woman was characterised by "wisdom, piety, humility, meekness, love, constancy, charity, good household government, godly devotion ... and a wholesome speech" (Trill, 1996: 33). In those times, these aspects were identified with the qualities which fitted the woman for her role as 'wife', 'mother' and 'mistress of the household'. Shakespeare's Volumnia certainly shares some of the Christian virtues mentioned above, such as wisdom, constancy, austerity in behaviour, a wholesome speech and devotion, though, in her case, 'devotion' to honour rather than to God.

That idea concerning the epitome of Christian woman was also fomented by Desiderius Erasmus, who, in the 1520s, advocated -in The New Mother- a mother's responsibility for the spiritual as well as physical nurturance of her children:

the main speaker of this colloquy advises that St Paul assured women they would be saved through childbearing, yet reminds them that their children must 'continue in the faith and love, with holinesse and modestie' in order to be likewise saved, 'so that you have not yet done the part of a mother, unlesse you first frame aright his tender bodie, and then his mind as tender as that with good education' (Wayne, 1996: 61). 
When the new mother answered that it was not in her power to assure her child's continuance in faith, her adviser replied, "It may be so, but for all that, vigilant admonition is of such force, that Paul thinked it to be laide to the mothers charge, if their children degenerate from godly courses" (Wayne, 1996: 61). According to that statement, in the Renaissance, mothers seem to have been the ones to blame for their children's behaviour. Alison Findlay (1999: 127) points out that "the Renaissance household had a protean quality with the potential to nurture and to destroy. Its enclosing walls were designed to protect those within from harm, but their embrace could also be suffocating ". ${ }^{11}$ This idea relates my interpretation of Volumnia as a Renaissance new mother to that of Adelman, who defended the Psychoanalytic approach, and considered her as a "non-nourisher" and a "cannibalistic mother".

Shakespeare certainly knew that, in Roman culture, "women enjoyed enormous power as mothers" (DuBois, 1985: 203), and in rearing sons Roman women were also considered "a fundamental instrument of the transmission of a culture" (Cantarella, 1987: 134). Thus he possibly found, in the figure of a Roman matron, a close parallel to the 'new mother' of the Renaissance, because if the latter was characterised, as it was mentioned above, by 'wisdom, constancy and good household government', among other things, a matron, according to the Oxford English Dictionary, is a "married woman or widow (often used with a suggestion of dignity and social position)".

The same as women in Renaissance England -with the obvious exception of Queen Elizabeth-, Roman women were rigorously excluded from all official participation in public affairs, whether as voters, senators or magistrates; the only exception was priesthood, to which they were admitted as Vestal Virgins. It is supposed that it was only through men that women could have any influence in public life: "whether by counsel, cajolement, manipulation or promise, a woman could only operate behind the scenes" (Bauman, 1992: 2). In relation to this, A. D. Nuttall explains that Volumnia had forged Coriolanus as an "instrument of war", but she needed an "instrument" to help her fulfil her political ambitions in Rome and the result was that she had erred somehow, since her son did not serve her purpose: "It is like trying to saw with a sword. At a word he will hack and kill, but he is set to shy away from the very idea of compromise or conciliation" (Nuttall, 1983: 116).

Whereas Nuttall affirms that Volumnia was really using Coriolanus to reach her political goals, Coppélia Kahn suggests that she was a mere instrument of the "dominant martial ideology". The latter insists that: "As a mother, she is of course subjected by the dominant ideology -but she is also instrumental to it, and thus central to the play's critique of virtus"12 (Kahn, 1997: 147). Lisa Lowe, on her part, has questioned feminist interpretations of Coriolanus that -in the same line as the Renaissance approach to the concept of motherhood- "attribute to the mother the sole responsibility of originating and producing murderous masculinity in her son", suggesting that the play dramatises "a symptom of cultural anxieties, particular to Elizabethan England, about the impossibility of achieving an absolute singular manhood" (Lowe, 1986: 89). And that would probably be an accurate interpretation of what was happening at the time Coriolanus was written -between 1605 
and 1608 approximately: England was ruled by James I, but the influence of the already deceased Elizabeth was certainly still felt in the country. ${ }^{13}$

When comparing Roman widows to their Renaissance counterparts, the latter "had somewhat more freedom to practise trades and often continued their husband's business either independently or with the assistance of a journey man or an apprentice" (Amussen, 1999: 87). Courtni Crump Wright (1993: 8) also shares that opinion when she states that: "the women of the Renaissance and the Elizabethan age were changing and broadening their control over their own lives" and she explains: "The rise to power of Mary I and Elizabeth provided the women with positive, aggressive, self-confident female role models who rules Renaissance England with determination and, sometimes, an iron hand". Nevertheless, she has to admit that, despite the fact that "the strength of these two monarchs encouraged the women to become more aware of the growing freedoms which awaited them", still they were under the authority of the men in the family.

Volumnia - a strong-willed and proud lady, standing, according to my analysis, both for the Roman matron and the independent Renaissance widow (a Renaissance 'new mother')- acts as the conscience of her son -and in this respect I would point out that her role parallels that of Calpurnia in relation to Caesar in Shakespeare's Julius Caesar: "as she tries to assist him in achieving greater heights and rising above the jealousy of others" (Wright, 1993: 11). Coriolanus's mother realises that Virgilia (his wife) lacks the courage to support the warrior and statesman her son embodies, since the latter regards him as a weak and threatened creature in danger. Therefore, she angrily rebukes her daughter-inlaw's squeamish fears for her husband's safety -"His bloody brow? O Jupiter, no blood!" (I.iii.33)- in the following terms:

Away, you fool! It more becomes a man

Than gilt his trophy. The breasts of Hecuba,

When she did suckle Hector, looked not lovelier

Than Hector's forehead when it spit forth blood

A Grecian swords contemning. (I.iii.34-38)

In those lines, Shakespeare has not only been careful to give Volumnia an appropriate literary allusion to the violent and heroic world of the Iliad, but he also shows Coriolanus' world is ruled by the values of a warrior culture, as Martindale (1994: 149) points out: "It is also, despite Volumnia's influence over her son (so that she can truly say in V.iii.63f. 'Thou art my warrior;/I holp to frame thee'), a society in which male values are more than usually dominant".

The Roman matron realises that, if she does not do anything to prevent it, Virgilia is also going to spoil her grandson's possibilities: "She is enchanted that her little grandson would rather see the swords and hear the drum, than look upon his school-master" (Shaw, 1990: 32). Virgilia is the embodiment of Roman and Renaissance domestic virtues as Volumnia is the female embodiment of public virtues, since - being a widow- the latter 
does not have to be relegated to the house, but she can take up her deceased husband's public role.

Pamela Joseph Benson argued that Renaissance humanists followed two alternatives for the model woman: "either the 'justice' model, which contended women could possess the cardinal virtues along with men, or the 'care' model, which glorified women's superior moral nature and natural virtue" (Benson, 1992: 45). According to that, and to what has been stated so far, I shall conclude that Shakespeare's approach to motherhood in Volumnia is so rich and realistic that it presents us with an admirable woman, who has deserved the attention of feminist critics from different perspectives (ranging from the Psychoanalysis, to the political perspectives: Cultural Materialism and New Historicism) and who shares characteristics both with and 'new mother' (the 'love' model) of the Renaissance-due to her superior moral nature, natural virtues, and decisive role in the bringing up of her son-, and with the staunch Roman matron (the 'justice' model), who would sacrifice everything for her loyalty to Rome, even at the risk of breaking her own heart.

\section{Notes}

1. See The Woman's Part: Feminist Criticism of Shakespeare (edited by Carol Thomas Neely et al., 1980), Political Shakespeare: New Essays in Cultural Materialism (edited by Jonathan Dollimore \& Alan Sinfield, 1985), Shakespeare Reproduced: the Text in History and Ideology (edited by J. Howard and Marion F. O'Connor, 1987), Clamorous Voices: Shakespeare's Women Today (by Carol Rutter, 1988), The Double Standard in Shakespeare and Related Essays: Changing Status of Women in 16th and 17th Century England (by Sarup Singh, 1988), Women in Shakespeare (by Judith Cook, 1990), Shakespeare Left and Right (by Ivo Kamps, 1991), Suffocating Mothers: Fantasies of Material Origin in Shakespeare's Plays, Hamlet to The Tempest (by Janet Adelman, 1992), The Women of Shakespeare's Plays (by Courtny Crump Wright, 1992), The Weyward Sisters: Shakespeare and Feminist Politics (edited by Dimpa Callaghan, 1994), As She Likes It: Shakespeare's Unruly Women (by Penny Gay, 1994), Shakespeare and Gender (edited by Deborah E. Barker \& Ivo Kamps, 1995), Shakespeare and the Nature of Women (by Juliet Dusinberre, 1996), Feminist Readings of Early Modern Culture (edited by Valery Traub et al,, 1996), Women's Worlds in Shakespeare's Plays (by Irene G. Dash, 1997), The Usurer's Daughter: Male Friendship and Fictions of Women in Sixteenth-Century England (by Lorna Hutson, 1997), Women Reading Shakespeare 1660-1900 (by Ann Thompson, 1997), Roman Shakespeare. Warriors, Wounds, and Women (Coppélia Kahn, 1997), Transforming Shakespeare: Contemporary Women's Re-Visions in Literature and Performance (edited by Marianne Novy, 1999), Shakespeare Feminine Endings: Disfiguring Death in the Tragedies (by Philippa Berry, 1999), A Feminist Perspective on Renaissance Drama (by Alison Findlay, 1999), Showing Like a Queen: Female Authority and Literary Experiment in Spenser, Shakespeare and Milton (by Katherine Eggert, 2000), A Feminist Companion to Shakespeare (edited by Dympa Callaghan, 2001) and Shakespeare, Feminism and Gender (by Kate Chedgzoy, 2001).

2. Dympna Callaghan (2001 [2000]: xi) laments that: "In my more distrusttul moments, I sometimes feel that feminist Shakespeareans are a persecuted minority, vulnerable to attack from all sides. More reactionary non-(if not anti-)feminists claim that feminism has 'gone too far' and 
is only outlandishly brought into juxtaposition with the venerable activities of Shakespearean scholarship."

3. For the purpose of this article I am integrating both theories (Cultural Materialism and New Historicism) since, according to Rex Gibson (1998: 39), they are "closely related": "In Shakespeare scholarship two major, closely related approaches assert the intimate relationship of culture (Shakespeare) and material factors (economics). These are new historicism, which is largely American, and cultural materialism, which is largely British."

4. In relation to the subject of 'creation', Janet Adelman (1992: 152) interprets the attack against Corioli "both as a rape and a rebirth", understanding "intercourse" as "a literal return to the womb, from which one is reborn, one's own author". Therefore, "the fantasy of self-authorship is complete when Coriolanus is given his new name, earned by his own actions."

5. See also Barron, David B. (1962): "Coriolanus: Portrait of the Artist as Infant", where oral frustration is also interpreted as central to the character of Volumnia's son. In relation to the phallic meaning of the play, see Hoffling, Ch. K. (1957): "An Interpretation of Shakespeare's Coriolanus", Stoller, R. J. (1966): "Shakespearean Tragedy: Coriolanus" and Wilson, E. Jr. (1968): "Coriolanus: The Anxious Bridegroom".

6. Shakespeare's principal source for Coriolanus was Plutarch's Lives, in Thomas North's translation (2nd. ed., 1595). The references to Plutarch's work in this article are from North's translation of The Life of Martius Coriolanus, in T. J. B. Spencer's Shakespeare's Plutarch (1964).

7. Bauman explains that the educated matron subjected the problems of society in general, and of women in particular, to "searching scrutiny" and continues stating that "women's involvement in public affairs took on new, and more sophisticated, dimensions" (Bauman, 1992: 4). According to Livy, it was "Coriolanus's mother, Veturia [notice that he does not call her Volumnia], who led a deputation of women to her son's camp to beg him not to attack Rome. Writers of the late Republic and Principate disclose the existence of an acute controversy as to whether the women acted with official authority or on their own initiative" (Bauman, 1992: 9), but Plutarch, on his part, assures that it was not actually Volumnia who had the idea of going in search of her son, to make him realise the implications of his deeds, but Valeria, Virgilia's friend (Spencer, 1968 [1964]: 351).

8. Lucking (1996: 413-14) explains that: "The idea that his own mother, who more than any other person has been responsible for inculcating his insatiable craving for a name, might be moved by allegiance to her city to render that name synonymous with betrayal, is intolerable to Martius. For the first time he is compelled to recognise what has always been the case: that his reputation, his name, and hence in the final analysis his very identity, are not in his own hands, that he does not possess an exclusive monopoly on language, that neither in the literal nor the figurative sense can any man be author of himself. In capitulating to his mother at this point he is tacitly deferring to the authority of the community in whose codes he is inscribed, and it is dramatically very appropriate that he should be -as the eloquent scene direction 'Holds her by the hand silent' intimates (V.iii.183)- left quite literally without words".

9. Cynthia Marshall (1996: 101) explains that Volumnia expresses the "overdetermined Roman attitude toward martial violence: blood, she says, 'more becomes a man / Than gilt his trophy' (I.iii.39-49). She 'thank[s] the gods for't' on hearing that her son has been hurt (II.i. 120), and proudly discusses the locations and number of his wounds".

10. "For women, the most important humanist works appearing during that period were Juan Luis Vives's Instruction of a Christian Woman (1529), as well as his Plan of Study for Girls (1523); 
Roger Ascham's The Schoolmaster (1570); Thomas Elyot's Defence of Good Women (1540); and John Aylmer's defence of Elizabeth's rule, A Harbour for Faithful and True Subjects (1959 [sic]), against John Knox's attack on women rulers, The First Blast of the Trumpet against the Monstrous Regiment of Women (1558)" (Smith 1998: 11).

11. It is worth pointing out that a twentieth-century version of William Shakespeare's Coriolanus exploits this aspect of the relationship between mother and son. John Osborne, in his adaptation, entitled $A$ Place Calling Itself Rome (1973), inserts an additional scene which does not exist in Shakespeare's play, nor is it reported in Plutarch's Lives either. From the beginning of the play we are aware of the enormous influence Volumnia exercises over her son, due to the fact that Coriolanus, in his nightmares, subconsciously wishes his mother's death, in an attempt to get rid of that suffocating influence which, according to Osborne's view, is asphyxiating him.

12. For more information about the nature of virtue and fame see Manuel Cerezo's Plutarco. Virtudes y vicios de sus héroes biográficos (1996).

13. Volumnia had to exercise her enormous influence on her son as a means of reaching her own goals because, in the society she lived in, as well as in Shakespeare's own time, the roles of each gender were very clearly defined. Geraldo U. de Sousa, in Shakespeare's Cross-Cultural Encounters (1999), in 1 Henry $I V$, referring to Joan of Arc, explains that, "Joan's violation of gender roles, manifested as an exchange, disturbs the English characters' sense of cultural stability" (Sousa, 1999: 50).

\section{Works Cited}

Adelman, Janet (1992): Suffocating Mothers. Fantasies of Maternal Origin in Shakespeare's Plays, Hamlet to The Tempest. London: Routledge.

Amussen, Susan Dwyer (1999): "The Family and the Household". In D. S. Kastan ed., $A$ Companion to Shakespeare. Oxford: Blackwell, 85-99.

Barker, Deborah and lvo Kamps (1995): Shakespeare and Gender: A History. London: Verso.

Barron, David B. (1962): "Coriolanus: Portrait of the Artist as Infant". American Imago 19: 171-193.

Bauman, Richard A. (1992): Women and Politics in Ancient Rome. London: Routledge.

Belsey, Catherine (1991): "A Future for Materialist Feminist Criticism?". In V. Wayne ed., The Matter of Difference. Materialist Feminist Criticism of Shakespeare. Hemel Hempstead: Harvester Wheatsheaf, 235-244.

Benson, Pamela J. (1992): The Invention of the Renaissance Woman. University Park: Pennsylvania State University Press.

Berry, Philippa (1999): Shakespeare's Feminine Endings: Disfiguring Death in the Tragedies. London: Routledge.

Bliss, Lee (2000): The New Cambridge Shakespeare: Coriolanus. Cambridge: Cambridge University Press.

Callaghan, Dympna (ed.)(1994): The Weyward Sisters: Shakespeare and Feminist Politics. London: Blackwell.

. (2001 [1999]): Shakespeare Without Women: Representing Gender and Race on the Renaissance Stage. London: Routledge. . (2001 [2000]): A Feminist Companion to Shakespeare. Malden (Mass.): Blackwell Publishers Ltd. 
Cantarella, Eva (1987): Pandora's Daughters: The Role and Status of Women in Greek and Roman Antiquity. Trans. M. B. Fant. Baltimore: Johns Hopkins University Press.

Cerezo, Manuel (1996): Plutarco. Virtudes y vicios de sus héroes biográficos. Lleida: Edicions de la Universitat de Leida.

Chedgzoy, Kate (2001): Shakespeare, Feminism and Gender. New York: Palgrave.

Cook, Judith (1990): Women in Shakespeare. London: Virgin Books.

Dash, Irene G. (1997): Women's Worlds in Shakespeare's Plays. Newark: University of Delaware Press.

Dollimore, Jonathan and Alan Sinfield (eds.)(1985): Political Shakespeare: New Essays in Cultural Materialism. Ithaca (N. Y.): Cornell University Press.

DuBois, Page (1985): "A Disturbance of Syntax at the Gates of Rome". Stanford Literary Review 2: 185-208.

Dusinberre, Juliet (1996): Shakespeare and the Nature of Women. Basingstoke: Macmillan.

Eggert, Katherine (2000): Showing Like a Queen: Female Authority and Literary Experiment in Spenser, Shakespeare and Milton. Philadelphia: University of Pennsylvania Press.

Findlay, Alison (1999): A Feminist Perspective on Renaissance Drama. Oxford: Blackwell Publishers LTD.

Fitzmaurice, James ed. (1997): Margaret Cavendish: Sociable Letters. New York: Garland Publishing.

Gay, Penny (1994): As She Likes It: Shakespeare's Unruly Women. London: Routledge.

Gibson, Rex (1998): Teaching Shakespeare. Cambridge: Cambridge University Press.

Hofling, Charles K. (1957): "An Interpretation of Shakespeare's Coriolanus". American Imago 14: 407-35.

Howard, Jean and Marion O'Connor (1987): Shakespeare Reproduced: The Text in History and ldeology. New York: Methuen.

Hutson, Lorna (1997): The Usurer's Daughter: Male Friendship and Fictions of Women in Sixteenth-Century England. London: Routledge.

Kahn, Coppélia (1997): Roman Shakespeare: Warriors, Wounds, and Women. London: Routledge. Kamps, Ivo (1992 [1991]): Shakespeare Left and Right. London: Routledge.

Kastan, David Scott (1999): A Companion to Shakespeare. Oxford: Blackwell Publishers Ltd. Kott, Jan (1969 [1966]): Apuntes sobre Shakespeare. Barcelona: Editorial Seix Barral, S. A. Lowe, Lisa (1986): "Say I play the man I am': Gender and Politics in Coriolanus". Kenyon Review $8(4)$ : 86-95.

Lucking, David (1996): "The Price of One Fair Word': Negotiating Names in Coriolanus". Kenyon Review 8 (4): 86-95.

Marshall, Cynthia (1996): "Coriolanus, Gender, and the Theatrical Construction of Interiority". In V. Traub et al., eds., Feminist Readings of Early Modern Culture. Cambridge: Cambridge University Press, 93-118.

Martindale, Charles and Michelle Martindale (1994 [1990]): Shakespeare \& The Uses of Antiquity. London: Routledge.

Neely, Carol Thomas (1983): The Woman's Part: Feminist Criticism of Shakespeare. Urbana: University of Illinois Press.

Newton, Judith and Deborah Rosenfelt (1985): Feminist Criticism and Social Change. New York: Methuen. 
Novy, Marianne (ed.)(2000 [1999]): Transforming Shakespeare: contemporary women's re-visions' in literature and performance. Hampshire: Palgrave.

Nuttall, A. D. (1983): A New Mimesis. Shakespeare and the Representation of Reality. London: Methuen.

Osborne, John (1973): A Place Calling Itself Rome. London: Faber \& Faber.

Rutter, Carol (1988): Clamorous Voices: Shakespeare's Women Today. London: The Women's Press, Co.

Shaw Fairman, Patricia (1990): "Ale Wives, Old Wives, Widows and Witches: the Older Woman in English Renaissance Literature". In J. Sánchez. ed., Proceedings of the I National Conference of the Spanish Society for English Renaissance Studies. Zaragoza: University of Zaragoza, 9-35.

Singh, Sarup (1988): The Double Standard in Shakespeare and Related Essays: Changing Status of Women in 16th and 17th Century England. Delhi: Kornak Publishers Pvt, Ltd.

Smith, Hilda L. (1998 [1996]): "Humanist Education and the Renaissance Concept of Woman". In H. Wilcox, ed., Women and Literature in Britain 1500-1700. Cambridge: Cambridge University Press.

Sousa, Geraldo U. de (1999): Shakespeare's Cross-Cultural Encounters. Basingstoke: Macmillan Press Ltd.

Spencer, T. J. B. (1968 [1964]): Shakespeare's Plutarch. Harmondsworth: Penguin Books.

Stoller, Robert J. (1966): "Shakespearean Tragedy: Coriolanus". Psychoanalytic Quarterly, 35: 263-74.

Thompson, Ann and Sasha Roberts (eds.)(1997): Women Reading Shakespeare, 1660-1900: An Anthology of Criticism. Manchester: Manchester University Press.

Traub, Valery et al. (eds.)(1996): Feminist Readings of Early Modern Culture. Cambridge: Cambridge University Press.

Trill, Suzanne (1996): "Religion and the Construction of Femininity". Women and Literature in Britain 1500-1700. In Helen Wilcox, ed., Cambridge: Cambridge University Press, 30-55.

Wayne, Valerie ed. (1991): The Matter of Difference. Materialist Feminist Criticism of Shakespeare. Hemel Hempstead: Harvester Wheatsheaf.

Wayne, Valerie (1996): "Advice for Women from Mothers and Patriarchs". In H. Wilcox, ed., Women and Literature in Britain 1500-1700. Cambridge: Cambridge University Press, 56-79.

Wilcox, Helen (1998 [1996]): Women and Literature in Britain 1500-1700. Cambridge: Cambridge University Press.

Wilson, EmmettJr. (1968): "Coriolanus: The Anxious Bridegroom". American Imago 25: 224-41. Wright, Courtni Crump (1993): The Women of Shakespeare's Plays. Lanhan (Maryland): University Press of America, Inc. 